\title{
Collection, Utilization, and Preservation of Genetic Resources in Vaccinium
}

\author{
James R. Ballington ${ }^{1}$ \\ Horticultural Science Department, North Carolina State University, Raleigh, NC 27695-7609
}

Vaccinium L. is one of the major genera in the tribe Vacciniae of the subfamily Vaccinoiodae of the Ericaceae (Stevens, 1969). The Vacciniae include all the Ericaceae with inferior ovaries, and are also typically characterized as having fleshy, more-or-less edible fruits commonly referred to as "blueberries," even though in a number of species the fruits are not blue. The genus includes $\approx 400$ species worldwide, and occurs on all continents except Antarctica and Australia (Luby et al., 1991). It also includes cranberries, bilberries, lingonberries, whortleberries, deerberries, and species referred to by any number of other common names in various parts of the world. Some species of Vaccinium are also commonly called huckleberries, but this name is more properly applied to species in the very closely related genus Gaylussacia $L$. The genus includes 30 sections (subgenera) as currently circumscribed (Stevens, 1969).

Fruit harvested from wild populations of Vaccinium species have made significant contributions to the human diet for thousands of years (Darrow and Camp, 1945; Hunn and Norton, 1983). Native stands of several species have been managed for fruit production for at least 1000 years, especially the lowbush blueberry, in New England, the upper midwest, and eastern Canada in North America (Hall et al., 1979; Yarborough, 1997).

Three commercial cultivated fruit crops have been developed from species and species hybrids in Vaccinium. These include: the cultivated and semi-cultivated blueberries, derived from species in Vaccinium section Cyanococcus A. Gray, from eastern North America; the large or American cranberry, developed from V. macrocarpon Ait. $(2 \mathrm{n}=2 \mathrm{x}=24)$, a North American species in section Oxycoccus (Hill) Koch; and the lingonberry, V. vitis-idaea $L .(2 \mathrm{n}=2 \mathrm{x}=24)$, in section Vitis-idaea (Moench) Koch, a circumboreal species (Galletta and Ballington, 1996). The recent introduction of cultivars of the tetraploid

Received for publication 22 May 2000. Accepted for publication 13 June 2000. The cost of publishing this paper was defrayed in part by the payment of page charges. Under postal regulations, this paper therefore must be hereby marked advertisement solely to indicate this fact.

${ }^{1}$ E-mail address: jim_ballington@ncsu.edu small cranberry (V. oxycoccos L.) will add some additional diversity to the cranberry group (Pliszka, 1993). Development of the blueberry and cranberry industries has occurred primarily in North America, while the lingonberry industry has developed primarily in Europe; all of them are of fairly recent origin. Commercial cranberry production began in 1816 in Massachusetts, and commercial lowbush blueberry [mainly $V$. angustifolium Ait. $(2 \mathrm{n}=4 \mathrm{x}=48)$, but including $V$. myrtilloides Michx. $(2 \mathrm{n}=2 \mathrm{x}=24)$ ] production began with the canning of fruit in the 1860s in New England. Efforts to domesticate rabbiteye blueberry [V. ashei Reade $(2 \mathrm{n}=6 \mathrm{x}=72)]$ began in northwestern Florida near the end of the 19th century, and the major type of cultivated blueberry, the highbush blueberry [primarily V. corymbosum L. $(2 \mathrm{n}=4 \mathrm{x}=48$ forms)], was developed entirely in the 20th century. Lingonberry cultivation is most recent. Domestication research with lingonberry did not begin until the 1960s, and 12 improved cultivars have been released over the last 30 years (Gustavsson, 1997).

Cranberry production in all of North America now exceeds 200,000 $\mathrm{t}$ annually, on 16,000 ha (Caruso, 1997; Food and Agriculture Organization, 1999). Total annual production of commercial blueberries in North America approaches 140,000 t (Food and Agriculture Organization, 1999; Trinka, 1997; Yarborough, 1997;). This includes the semicultivated lowbush blueberries grown commercially on 52,800 ha of managed wild stands, which accounted for $40 \%$ of total commercial production in 1995. Cultivated blueberries include rabbiteye and the standard highbush, southern highbush, and Minnesota halfhigh types. The area devoted to cultivated blueberries in North America increased 34\% (from 15,700 to 21,000 ha) from 1986 to 1996 and continues to increase, while production increased $48 \%$ (from 56,700 to 83,200 t) during this same period (Trinka, 1997). In 1995, cultivated types accounted for $60 \%$ of total North American blueberry production. While the majority of cultivated blueberry hectarage is in North America, commercial industries (mainly highbush) are also firmly established in Europe, Australia, New Zealand, and Chile (Galletta and Ballington, 1996; Munoz, 1993). Commercial lingonberry production primarily involves harvesting of berries from wild populations in northern Europe, Asia, and North America, with cultivated produc- 
tion still in its infancy compared with other Vaccinium crops. Thirtyfive hectares of cultivated plantings were reported to be in production in Germany in the early 1990s (Gustavsson, 1997), and additional plantings have been established in both Europe and North America. Demand for lingonberry products is providing the current impetus for expanding production; however, future expansion will probably be dependent on development of additional markets and products, as has occurred with cranberry.

Production of commercial Vaccinium crops $(420,570 \mathrm{t})$ is by no means of the same magnitude as that of major deciduous fruit crops such as apples (Malus $\times$ domestica Borkh.) (60.2 million t) (Food and Agriculture Organization, 1999); however, both hectarage and production continue to increase. In addition to the unique flavors for which blueberries, cranberries, and lingonberries have been appreciated over the years, recent information on their health benefits promises to contribute significantly to increasing production in the $21 \mathrm{st}$ century (Camire, 1997; Dierking et al., 1993; Joseph et al., 1999; Prior et al., 1998).

Over the last 20 years, serious concerns have been raised over the very restricted germplasm base in commercially important cultivars of the various cultivated Vaccinium crops (Galletta and Ballington, 1996), and breeders have made conscious efforts to broaden this base in recent cultivar releases (Ballington, 1990; Ehlenfeldt, 1997; Hancock et al., 1995; Lyrene, 1988; Lyrene and Brooks, 1995). However, continuing and increased efforts are needed, particularly in broadening cytoplasmic diversity (Hancock and Krebs, 1986). The purpose of this report is to document the progress that has been made in collecting, utilizing, and preserving the germplasm needed to meet current and future needs in Vaccinium crops.

\section{COLLECTION}

\section{Availability of germplasm}

Vaccinium angustifolium and V. corymbosum are very wideranging species, and the genetic resources presently available in their genepools are almost unlimited and relatively accessible (Galletta and Ballington, 1996). If $V$. ashei is lumped together with the closely related, wider-ranging, and completely interfertile "species" $V$. amoenum Ait. (sensu Camp, 1945) into a single genepool, as suggested by Lyrene (1988), then the genetic resources in this genepool are also quite extensive. The diploid species $V$. darrowi Camp is the fourth species that has played a major role with regard to germplasm contributions to the cultivated blueberry genepool. Its contributions of lowchilling, heat tolerance, and improved quality to southern highbush cultivar improvement were possible through production of viable unreduced gametes (Ballington, 1990). Vaccinium darrowi is native to Florida, southern Georgia, and along the Gulf Coast of the United States to Texas (Vander Kloet, 1988). The loss of germplasm in this species is of concern because of commercial and residential development in Florida and along the Gulf Coast (Lyrene, pers. comm.). Vaccinium angustifolium, $V$. ashei, $V$. corymbosum, and $V$. darrowi are by no means the only species of potential value in improving cultivated blueberries, and possibilities extend across the primary, secondary, and tertiary genepools of each type.

Cranberries are native to habitats best described as wetlands, and the destruction of wetlands in a number of regions where $V$. macrocarpon grows may have significantly reduced populations of native germplasm of this species (Luby et al., 1991). Federal legislation in the United States protecting wetlands from destruction has moderated the rate of loss of these habitats. Since the range of $V$. macrocarpon greatly exceeds the current limits of the areas where wetlands destruction has been extensive (Vander Kloet, 1988), significant wild germplasm of this species is still available for collection, preservation, and utilization. Vaccinium oxycoccos is circumboreal in distribution and still relatively abundant throughout its range (Vander Kloet, 1988).

Lingonberries also occur throughout the boreal regions of the northern hemisphere (Luby et al., 1991), and, as with lowbush and highbush blueberries, almost unlimited and relatively accessible genetic resources are available.

\section{History of collection}

Blueberry germplasm collection began in earnest in 1908 with F.V. Coville $(1910,1937)$ and continued for a number of years, especially in cooperation with Elizabeth White of Whitesbog, N.J. This cooperative effort resulted in the collection and selection of the core of elite wild $V$. corymbosum genotypes, along with the $V$. angustifolium clone 'Russell', which served as the germplasm base for the cultivars that established the early highbush blueberry industry. The V. corymbosum clone 'Crabbe-4', from southeastern North Carolina, was incorporated into this genepool a little later to develop highbush cultivars resistant to blueberry stem canker [caused by Botryospheria corticis (Demaree and Wilcox) Arx and Müller], which devastated most of the early USDA cultivar releases when they were planted in eastern North Carolina and other southern areas in the United States.

Collection of V. ashei for domestication began even earlier. In 1893 M.A. Sapp transplanted "selected" native seedlings into a cultivated planting in west Florida (Moore, 1966). This strategy of transplanting wild plants directly into cultivation allowed a significant industry to develop quickly in Florida and six other southern states by the early 1920s. Unfortunately, the nurserymen who sold the majority of the plants did not follow Sapp's lead in selling only "selected" wild plants, and most plants produced very poor quality fruit. About this same time the first highbush blueberry cultivars were released by the USDA, and the resulting competition from the higher quality improved highbush cultivars led to the demise of the early rabbiteye industry in the South (Sharpe, 1954). In this author's experience, fruit from "selected" forms of $V$. ashei from west Florida, although typically dark in color, have good to excellent quality. The cultivated blueberry industry might have evolved differently if sellers of early rabbiteye blueberry plants had followed Sapp's lead and only dug plants producing good quality fruit for sale to growers in the South. The plants from many of these early $V$. ashei plantings have been quite persistent and they, and primarily their seedlings, have become a permanent component of the flora in a number of areas in the southeastern United States not formerly occupied by this species (Ballington et al., 1982; Lyrene and Sherman, 1980).

Additional $V$. ashei selections were made by individual blueberry enthusiasts in the 1930s and early 1940s. Jackson M. Batchelor, horticulturist with the U.S. Soil Conservation Service, was instrumental in assembling the more promising genotypes for systematic evaluation by USDA and state experiment station researchers. These latter selections, collected from southeastern Georgia and north and west Florida, became the primary germplasm base for rabbiteye blueberry improvement from the initial efforts up to the present (Batchelor, 1965).

Also in the late 1930s and early 1940s, G.M. Darrow and his associates, W.H. Camp, E.B. Morrow, and J.M. Batchelor, made additional significant blueberry collections in the southeastern United States, with much of the effort concentrated in the southern Appalachians. These efforts resulted in the first systematic collections of elite germplasm of the high-elevation, hexaploid blueberry species $V$. constablaei Gray and its subsequent use in interspecific hybridization with $V$. ashei. It also led to the collection of the stem canker-resistant $V$. corymbosum genotype NC 102 in southeastern North Carolina. These collection efforts were essentially terminated with the entry of the United States into World War II. They are documented in a series of letters among the participants that are maintained at Beltsville, Md., and Raleigh, N.C.

R.H. Sharpe began collecting elite clones of $V$. darrowi for establishment, evaluation, and utility in blueberry improvement in 1951 (Lyrene, 1998). His collections have provided all the germplasm of this species involved in the development of southern highbush cultivars up to this time.

Elite native genotypes of $V$. angustifolium have served as the basis for lowbush blueberry cultivar improvement by the USDA, Agriculture Canada, and state experiment stations in Maine, Michigan, Minnesota, New Hampshire, West Virginia, and Wisconsin (Galletta and Ballington, 1996). The Agriculture Canada program at Kentville, N.S., is the only program that has released improved lowbush cultivars, and is the only lowbush improvement program still in existence. 
The $V$. angustifolium genotypes collected have also been utilized in halfhigh blueberry improvement work in a number of the aforementioned states in the United States (Galletta and Ballington, 1996).

Collection of cranberry germplasm has a longer history than does that of blueberry germplasm. The majority of the $100+$ wild $V$. macrocarpon selections named as cultivars were collected in the 19th century by individual cranberry enthusiasts (Chandler and Demoranville, 1958). Only five of these selections account for $90 \%$ of cultivated cranberry production, and two of the five, 'Early Black' and 'Searles', alone account for $\approx 60 \%$ (Luby et al., 1991). Many of these old, named clones are being maintained at Chatsworth, N.J., and Corvallis, Ore.

\section{Recent collections}

G.J. Galletta and his associates conducted USDA Plant Introduction Service-sponsored Vaccinium germplasm collections in southern, mid-south, middle Atlantic, New England, and upper midwestern states in the United States from 1965 through 1969. Altogether, collections were conducted in 10 states and included all section Cyanococcus species except $V$. boreale Aalders and Hall and $V$. hirsutum Buckley. In addition, modest collections of $V$. stamineum $L$. [section Polycodium (Raf) Rehder], V. arboreum Marsh. [section Batodendron (Nutt.) A. Gray], and the true huckleberry species, Gaylussacia frondosa L., were also included. These were the most extensive collections made up to that time, and germplasm from these collections is still being utilized in the North Carolina blueberry improvement program.

J.R. Ballington also began collecting Vaccinium germplasm in the mid-1960s. In the late 1970s, his collecting efforts increased significantly after he assumed responsibility for blueberry breeding and genetics at North Carolina State Univ. Collections concentrated on species in section Cyanococcus in the southeastern United States and southern Appalachians. All section Cyanococcus species native to these regions were collected, with emphasis on V. amoenum, V. ashei, V. constablaei, V. corymbosum, V. elliottii Chap., V. pallidum Ait., and V. simulatum Sm. Collections from 1978 through 1985 were summarized in three in-house publications (Ballington et al., 1979, 1982, 1985). Collections in the southern Appalachians in 1986 were supported by funds from the USDA, ARS National Clonal Germplasm Repository at Corvallis, Ore. (NCGR-Corvallis). Major collection associates included D.V. Barkley, W.B. Kirkman, C.A. Walker, B.S. Megalos, B. Buckley, U. Buckley, F.A. Ballington, M.A. Streit, J.A. Payne, A.D. Draper, N. Vorsa, P.M. Lyrene, D. Finch, K. Williams, and S.C. Hokanson. Vaccinium corymbosum was also collected in southern Michigan (with J.F. Hancock and M.P. Pritts) and central Pennsylvania (with K.E. Hummer). Major collections of species in section Myrtillus Dumort were also made in Oregon and Washington in 1985 (with J.J. Luby and O.L. Jahn) (Ballington et al., 1988), and in section Pyxothamnus (Nutt.) Sleumer in Ecuador in 1990 (with J.L. Luteyn, M.M. Thompson, K. Romoleroux, and R. Castillo) (Ballington et al., 1993a). In addition, over this entire time frame, modest collections of species in sections Batodendron, Herpothamnus (Small) Sleumer, Oxycoccoides Hooker fil', Polycodium and Vaccinium L. were also made, as well as all eastern North American species of Gaylussacia L. except G. brachycera (Michx) A. Gray. Collections in the Pacific Northwest, Ecuador, and the southeastern United States in 1995-98 were supported by USDA Plant Exploration Grants. The germplasm from these latter collections, along with that collected in the southern Appalachians in 1986, was either shared with NCGRCorvallis, in the case of sections Cyanococcus, Batodendron, Polycodium, and Pyxothamnus, or was forwarded in total to the Repository, with species in other sections.

P.M. Lyrene began collecting Vaccinium germplasm for potential use as parents soon after he assumed responsibility for breeding and genetics at the Univ. of Florida in 1974. He has primarily collected in Georgia, Florida, and southern Alabama, and his collections included all species indigenous to this region. He received a USDA Plant Exploration Grant for collection of $V$. ashei and $V$ corymbosum germplasm in southeastern Georgia and $V$. ashei in western Florida in 1984, and also made significant collections of $V$. constablaei in western North Carolina in the late 1980s and early 1990s.

J.F. Hancock and his students made extensive collections of $V$. angustifolium and V. corymbosum in Michigan during the course of their research in the 1980s and 1990s (Pritts and Hancock, 1984, 1985; Pritts et al., 1985).

Nicoli Vorsa and L.P. Bruederle of Rutgers Univ. received a USDA Plant Exploration Grant in 1988 to collect germplasm of diploid Vaccinium section Cyanococcus species for chemotaxonomic studies. This resulted in extensive population collections of these species, and a key publication clarifying the taxonomic relationships among them (Bruederle and Vorsa, 1994). Most of this germplasm continues to be maintained at Chatsworth, N.J.

Other individuals involved in collection of section Cyanococcus species from the 1960s through the 1990s include: P.R. Hepler (Univ. of Maine); W.B. Sherman (Univ. of Florida); J.J. Luby (Univ. of Minnesota); M. Lareau (St. Jean, Quebec); and A.D. Draper, R.J. Knight, C.L. Gupton, J.M. Spiers, C.E. Finn, and K.E. Hummer, all of the USDA.

J.J. Luby, J.F. Hancock, C.E. Finn, D. Barney, and R.E. Harrison have also been involved in collection of section Myrtillus species in the Rocky Mountains and/or northern Cascades in northwestern North America, as have K.E. Hummer and C.I. Wright (1996) in Alaska. W.B. Kirkman made extensive collections of species in section Herpothamnus in the late 1970s (Kirkman, 1987; Kirkman and Ballington, 1985). Vaccinium uliginosum L. (section Vaccinium) has also been collected by a number of workers in northern Europe for evaluation and for crossing studies with section Cyanococcus species (Luby et al., 1991). Gorbunov (1993) made extensive collections of this species in Siberia, which were then evaluated for self-fertility and fruit size characteristics. Hummer also made fairly extensive collections of this species in Alaska in 1996.

No major additional $V$. macrocarpon germplasm collections took place until 1990, when K. E.Hummer made systematic collections in the northeastern United States. These collection efforts were supported by funds from NCGR, Corvallis. Dr. Hummer and C.I. Wright (1996) also collected V. oxycoccos in Alaska in 1996 during an expedition supported by a USDA Plant Exploration Grant. During the late 1970s and the 1980s, W.B. Kirkman and J.R. Ballington made minor collections of $V$. macrocarpon in northeastern and western North Carolina, respectively.

Jean Allen and Calvin Sperling began collecting $V$. macrocarpon in the middle Atlantic states, as well as in Virginia and Tennessee, in 1992. Funding for these collections came from the USDA Plant Exchange office, rather than from the usual exploration funds. The main purpose of their work was identification of locations for in situ cranberry preservation, especially locations where $V$. macrocarpon appeared endangered.

Over a period of 20 years beginning in 1965, workers in Estonia collected and evaluated $\approx 800$ clones of tetraploid $V$. oxycoccos, identifying 20 elite genotypes, from which the five cultivars Kuresoo, Maima, Nigula, Soontagana, and Virussaare were chosen (Pliszka, 1993). Limited collection and selection of superior wild clones of tetraploid $V$. oxycoccos have also taken place in Finland (Hiirsalmi, 1988) and Latvia (Gronskis and Snickovskis, 1989). Gorbunov (1993) selected and collected elite forms of the hexaploid race of $V$. oxycoccos (syn. V. gigas Hagerup) from natural populations in western Siberia. Several of the best clones produced fruit weighing up to $1.5 \mathrm{~g}$ and/or yields up to $1 \mathrm{~kg} \cdot \mathrm{m}^{-2}$.

Germplasm collection of lingonberry began in the 1960s in northern Europe (Lehmushovi, 1977; Teär, 1972), primarily with $V$. vitisidaea var. vitis-idaea $\mathrm{L}$. All present cultivars are derived from selected wild materials of this botanical variety (Gustavsson, 1997). While most collections have taken place in Scandinavia, some have also been made in the Baltic States, Russia, and Japan (Gustavsson, 1997). Vaccinium vitis-idaea var. minus Lodd has also been collected in Canada (Estabrooks, 1997), and was a significant component of the Hummer Vaccinium collections in Alaska in 1996.

S.P. Vander Kloet, in conjunction with his taxonomic studies, has collected germplasm in many sections of Vaccinium over the last 30 years. 


\section{UTILIZATION}

\section{Highbush blueberries}

The primary genepool, i.e., tetraploid $V$. corymbosum, has been expanded significantly by using native germplasm in crosses with cultivated highbush. 'Pender', a recently introduced cultivar from North Carolina that can be harvested mechanically, resulted from crossing cultivated highbush with a small and firm-fruited, uplandadapted, wild $V$. corymbosum genotype from central South Carolina. 'Southmoon', from the Univ. of Florida program, has a wild $V$. corymbosum ( $V$. fuscatum Ait., sensu Camp, 1945) genotype from Alachua county, Fla., as one of its grandparents. Lyrene (pers. comm.) estimates that $5 \%$ to $10 \%$ of the genes in the Florida southern highbush genepool come from low-chilling, heat-tolerant wild $V$. corymbosum from northeast Florida and southeast Georgia. The southern highbush cultivars Duplin and Georgia Gem include the very hardy, wild $V$. corymbosum clone Ashworth in their genetic backgrounds. The release of 'Georgia Gem' also introduced 'Ashworth' cytoplasm into the cultivated highbush genepool.

Wild V. corymbosum has been important for many years as a source of resistance to blueberry stem canker in the southeastern United States. 'Crabbe-4' and 'NC 102' from North Carolina and 'Adams' from New Jersey have each served as useful sources of resistance to this disease. 'Echota', recently released from North Carolina, is the first highbush cultivar with 'NC 102' genes for stem canker resistance. The colchiploid V. corymbosum (V. atrococcum Heller, sensu Camp 1945) selection US 41, which is resistant to Phytophthora cinnamoni Rands, is also involved in the genetic background of elite selections in several breeding programs, but none of these has as yet been named as a cultivar.

Wild $x$ cultivated highbush crosses continue to be integral components of the breeding programs in Michigan and North Carolina. In both cases, the goal is productive, firm-, and small-fruited genotypes adapted to mechanical harvesting. The Michigan program involves wild $V$. corymbosum germplasm from Michigan and Quebec. In North Carolina, 30 elite $F_{1}$ (wild $x$ cultivated) highbush selections were identified in 1998. These involved $V$. corymbosum germplasm from North and South Carolina, Virginia, New Jersey, and Michigan. In these selections, the wild genotype was always used as the female parent in a conscious effort to broaden the cytoplasmic base in highbush blueberries. In North Carolina, native V. corymbosum from southern Michigan and central Pennsylvania have been particularly valuable as sources of genes for late blooming combined with early fruit maturity.

From the beginnings of highbush cultivar development, the secondary genepool in cultivated highbush has involved V. angustifolium. About half of the current highbush cultivars have some V. angustifolium germplasm in their genetic background (Galletta and Ballington, 1996). The "halfhigh" cultivars from the Minnesota program generally have a higher percentage of $V$. angustifolium genes than do standard highbush cultivars. Vaccinium angustifolium is a valuable source of genes for resistance to stem blight [caused by Botryosphaerea dothidea (Mouq.: Fr.) Ces. \& de Not.], which is a very important disease in warmer blueberry production regions (Ballington et al., 1993b; Buckley and Ballington, 1987). Stem blight-resistant $F_{1} s$ between $V$. angustifolium and cultivated highbush have been identified in North Carolina and are being systematically backcrossed to elite highbush cultivars. As with the wild $\mathrm{x}$ cultivated highbush selections noted above, $V$. angustifolium was always used as the female parent in these $F_{1}$ crosses to further broaden the cytoplasmic base in the cultivated highbush genepool.

The contributions of $V$. darrowi to southern highbush cultivar development have been well-documented (Hancock et al., 1995; Lyrene, 1998), especially in regard to the pioneering work of R.H. Sharpe and A.D. Draper. The southern highbush cultivars Georgia Gem, Cape Fear, Blue Ridge, Cooper, Gulf Coast, Legacy, and Sampson are derived from backcrosses of elite $V$. darrowi clone FLA4B X 'Bluecrop' hybrids to other, relatively unrelated, cultivated highbush genotypes. The unusual combination of plant adaptation, heat tolerance, and superior fruit quality from this combination has led
Hancock (1998) to incorporate these hybrids into his breeding program in Michigan. He found that full hardiness, in northern production regions, could be restored with three backcrosses to $V$. corymbosum, while retaining the desirable fruit qualities of this interspecific combination.

Sharpe also incorporated $V$. ashei into the southern highbush genepool through his pentaploid $V$. darrowi-V. ashei hybrids (Lyrene, 1998). Some of these hybrids were sufficiently fertile to produce at least partly fertile progeny when crossed to cultivated highbush, and further backcrossing and intercrossing restored full fertility. The southern highbush cultivars Flordablue, Sharpblue, Misty, Star, Southmoon, O’Neal, Reveille, Bladen, Duplin, Jubilee, Magnolia, Ozarkblue, and Summit have $V$. ashei and $V$. darrowi genes in their backgrounds, along with genes from $V$. angustifolium, cultivated $V$. corymbosum, and a minor contribution from $V$. tenellum Ait. Meyer and Ballington (1990) transferred resistance to feeding by the sharpnosed leafhopper (Staphytopius magdalensis Peoc.) (the vector of the blueberry stunt phytoplasma) from $V$. ashei to cultivated highbush through a series of backcrosses. However, no resistant cultivars have as yet resulted from this work.

The contributions of $V$. elliottii to highbush blueberry improvement in North Carolina continue to increase (Ballington, 1990), but hybridization involving this species has been discontinued in Florida. The $F_{1}$ hybrids between $V$. elliottii and cultivated highbush are extremely vigorous, with broad soil adaptation, but generally lack sufficient fruit quality to be named as cultivars. The $\mathrm{F}_{1} \mathrm{~s}$ also bloom very early. Backcrosses to cultivated highbush have produced a number of genotypes in North Carolina that are promising as potential cultivars. They retain broad soil adaptation, produce medium-size, high-quality fruit, and are adapted to mechanical harvesting. Vaccinium elliottii has also proved to be a very useful southern source of genes for resistance to stem blight. Vaccinium darrowi $x$ V. elliottii hybrids, such as Draper's 'US 388', are also very promising as parents to cross with cultivated highbush to develop additional southern highbush cultivars for the deep south.

\section{Rabbiteye blueberries}

Most cultivar improvement within the primary genepool in V.ashei has involved intercrossing elite selections basically derived from four or five original parents. The recurrent selection program in Florida, involving crosses among unrelated wild selections from south Georgia and northeast Florida, has been abandoned so that more resources can be devoted to breeding early-ripening southern highbush cultivars (Lyrene, 1988; pers. comm.). In North Carolina, limited outcrosses involving south Georgia and/or west Florida genotypes have been carried out and selections made from $F_{1}$ progenies. These selections are currently under evaluation to determine their potential value as parents in further intercrosses among germplasm unrelated to the present rabbiteye cultivated genepool or in backcrosses to the cultivated genepool. Crosses with $V$. amoenum have yielded some interesting early-ripening and aromatic-flavored selections, and because these two taxa appear to be part of a single genepool, they are included here. Since the range of $V$. amoenum extends farther north than that of $V$. ashei, the hybrids also tend to be more cold-hardy.

The secondary genepool of the rabbiteye blueberry expanded significantly with the development of hexaploid southern highbush genotypes (Dweikat and Lyrene, 1989; Ehlenfeldt and Vorsa, 1993). This promises to be a very productive means for combining highbush fruit quality and early-ripening traits with the adaptation and productivity traits of rabbiteye. Backcrossing highbush $x$ rabbiteye (or other pentaploids) back to rabbiteye is another feasible way to accomplish this (Laverty and Vorsa, 1991), but probably is not as efficient as making hexaploid intercrosses. Interspecific hybridization of $V$. ashei with $V$. constablae $i$ has been used since the beginnings of rabbiteye improvement. 'Little Giant' is the first $F_{1}$ hybrid cultivar derived from this interspecific combination. 'Snowflake' from the Florida program also has V. constablaei as one grandparent. Vaccinium constablaei $\mathrm{x}$ $V$. ashei hybrids and backcrosses continue to play a role in hexaploid blueberry improvement programs. Low-growing and profusely suckering plant habits are problems often encountered with this 
interspecific combination; however, certain parental combinations adequately overcome these shortcomings. Fruit quality of V. constablaei $x V$. ashe $i$ hybrids is often excellent, and the hybrids often exhibit the late bloom and early fruit maturity characteristics of the $V$. constablaei parent (Ballington et al., 1986). Lack of resistance to Phytophthora root rot and lack of resistance of flower buds to blueberry gall midge (Dasineura oxycoccana Johnson) have been major problems with $V$. ashei $x$ V. constablaei derivatives in Florida (Lyrene and Payne, 1995). Three-way crosses involving rabbiteye blueberry, V. constablaei, and hexaploid southern highbush genotypes may provide the best avenue for future improvements in cultivated hexaploid blueberries.

\section{Lowbush blueberries}

Cultivar improvement with lowbush has remained within the primary genepool (Aalders et al., 1975, 1977; Galletta and Ballington, 1996; Hall and Aalders, 1982; Hall et al., 1977, 1988).

\section{Cranberries}

Work in improving the cultivated cranberry (V. macrocarpon) has been limited, remaining almost exclusively within the primary genepool. However, in Finland, diploid forms of $V$. oxycoccos [syn. $V$. microcarpum (Turcz.) Hook. fil] have been successfully intercrossed with $V$. macrocarpon in attempts to develop hardier cranberries for the Scandinavian region (Lehmushovi et al., 1993). Vorsa (pers. comm.) has also recently produced viable, vigorous $\mathrm{F}_{1}$ hybrids between diploid $V$. oxycoccos from Alaska and cultivated V. macrocarpon.

\section{Lingonberries}

Cultivar development in this monotypic section of the genus is fairly recent and has taken place within the primary genepool (Gustavsson, 1997).

\section{The tertiary genepools and wide hybridization}

Intersectional hybridization in Vaccinium goes back to the early days of improvement with Coville (Cyanococcus-Polycodium) (Camp, 1945), Darrow (Cyanococcus-Pyxothamnus and CyanococcusHemimyrtillus) (Darrow and Camp, 1945), Shultz (Vitis-idaeaOxycoccus, Pyxothamnus-Oxycoccus, Pyxothamnus-Vitis-idaea, Pyxothamnus-Cyanococcus, Pyxothamnus-Myrtillus, and Cyanococcus-Vaccinium (Shultz, 1944), Doughty (CyanococcusVaccinium, Pyxothamnus-Cyanococcus and PyxothamnusOxycoccus)(Doughty, 1960, 1962), Meader(Vitis-idaea-Polycodium) (Meader, pers. comm.) and Ahokas (Oxycoccus-Vitis-idaea) (Ahokas, 1979). Lyrene and Ballington (1986) also reported additional successful intersectional combinations of Cyanococcus species with Batodendron and Herpothamnus species, along with Vitis-idaeaHerpothamnus, Herpothamnus-Pyxothamnus, and Bracteata NakaiHerpothamnus crosses. More recently, hybrids have been produced by Vorsa with Cyanococcus-Vitis-idaea, and Ballington with Cyanococcus-Myrtillus and Herpothamnus-Oxycoccus. Zeldin and McCown (1997) produced viable seedlings with Macropelma (Klotzsch) Hooker fil.-Vitis-idaea and Macropelma-Oxycoccus crosses. Over 50 years ago, Shultz (1944) noted that such crosses can be readily made, and occasionally sectional hybrids between $V$. myrtillus L. (section Myrtillus) and V. vitis-idaea (section Vitis-idaea) are observed in the wild in Europe (Ahokas, 1971). These $F_{1}$ intersectional hybrids typically display varying degrees of cytogenetic and morphological irregularities, and, in Vaccinium, reproductive and developmental barriers of these types typically appear in crosses only at the sectional or subgeneric level (Lyrene and Ballington, 1986).

Diploid $F_{1}$ sectional hybrids are typically sterile, or nearly so. However, this is not universally true, and partly fertile diploid $F_{1}$ s have occurred between $V$. tenellum and $V$. stamineum and $V$. darrowi and $V$. stamineum (both Cyanococcus $\times$ Polycodium combinations) (Lyrene and Ballington, 1986), V. vitis-idaea (section Vitis-idaea) $\times$ V. stamineum (Meader, pers. comm.), and $V$. darrowi $\times$ V. vitis-idaea
(Vorsa, pers. comm.). Zeldin and McCown (1997) found that partly fertile $V$. reticulatum Sm. (section Macropalma) $\times$ V. vitis-idaea $\mathrm{F}_{1} \mathrm{~s}$ could be successfully backcrossed to either parent species.

Cytogenetic and morphological irregularities are often evident to varying degrees with tetraploid $F_{1}$ intersectional hybrids as well; however, fertility and normal morphological development can sometimes be restored with backcrossing, as in the case of the numerous successful V. corymbosum (section Cyanococcus)-V. uliginosum (section Vaccinium) crosses reported (Luby et al., 1991; Lyrene, 1993). The Finnish blueberry cultivar Aron is derived from $V$. uliginosum $\mathrm{X}$ 'Rancocas' backcrossed to 'Rancocas' (Hiirsalmi and Lehmushovi, 1982). Gorbunov (1993) successfully produced viable hybrids between $V$. uliginosum and $V$. angustifolium and $V$. ashei, as well as with V. corymbosum.

Intersectional crosses involving genotypes of diploid species that produce unreduced gametes, when crossed with tetraploid genotypes of species from another section, can also result in partly fertile to fertile progeny that may exhibit behavior cytogenetically similar to that of the tetraploid Cyanoccoccus-Vaccinium hybrids noted above. Such hybrids have been reported several times in Cyanococcus-Pyxothamnus combinations. Doughty $(1960,1962)$ was the first to report successful crosses between cultivated highbush and the diploid section Pyxothamnus species V. meridionale Sw. (syn. V. corymbodendron Dunal.). Vaccinium corymbodendron is a potentially useful parent for frost resistance during bloom, and also has a very loose inflorescence that allows for easy fruit removal during mechanical harvesting (Luby et al., 1991). One tetraploid hybrid between $V$. corymbodendron and cultivated highbush and one between $V$. myrsinites Lam. (section Cyanococcus) and V. corymbodendron have been produced in North Carolina. The $\mathrm{F}_{1}$ between $V$. corymbodendron and cultivated highbush is at least partly fertile and was successfully backcrossed to highbush in 1998. However, its extreme susceptibility to powdery mildew [Microsphaerea vaccinii (Schwein.) Cooke and Peck] may limit its usefulness even in backcrosses. The $V$. myrsinites $\times$ V. corymbodendron $F_{1}$ appears to be only slightly fertile. Draper (Luby et al., 1991) produced a tetraploid $\mathrm{F}_{1}$ between cultivated highbush and $V$. ovatum in the 1970s. This tetraploid sectional hybrid was successfully backcrossed to both standard and southern highbush. Vaccinium ovatum is potentially useful as a parent for upland adaptation and drought resistance.

Mostly sterile, diploid, intersectional $F_{1}$ s may occasionally produce unreduced gametes and so produce partly to fully fertile progeny when backcrossed to tetraploid genotypes. This has been the case with Cyanococcus $\times$ Batodendron crosses at the Univ. of Florida (Lyrene, 1990). Vaccinium arboreum Marsh (section Batodendron) is droughtand heat-resistant, tolerant to higher $\mathrm{pH}$ and mineral soils, and produces very late-ripening, essentially inedible fruit with very large seeds. Crosses of $\mathrm{F}_{1}$ hybrids between $V$. darrowi and $V$. arboreum to highbush blueberry have yielded some fertile, very vigorous, uplandadapted genotypes (Lyrene, 1991). However, these are all late-ripening, berries have fairly large seeds, and none of the progeny has yet met commercial quality standards. If early ripening is of no consequence, or if late-ripening is a program goal, then further backcrosses and/or intercrosses of this intersectional backcross combination appear promising. Later generation segregates from this intersectional combination appear particularly promising for extending blueberry culture to upland, droughty, mineral soils without extensive soil modification (Lyrene, 1993).

Occasionally, diploid $\mathrm{F}_{1}$ intersectional hybrid combinations produce amphidiploid progeny, and Camp (1945) proposed that this was the origin of $V$. hirsutum. Two examples of this have occurred in the North Carolina breeding program. The first involved crossing ' $\mathrm{NC}$ 2267' (1/4 diploid V. corymbosum, 3/4 V. darrowi) (section Cyanococcus) with a selection of $V$. ovatum (section Pyxothamnus). One seedling selection, 'NC 3048', resulted from 275 pollinations and is tetraploid (Ballington et al., 1997). 'NC 3048' is at least partly fertile and has been successfully backcrossed to tetraploid section Cyanococcus genotypes. It has proven more successful as a male parent in terms of numbers of seedlings produced. 'NC 3048' is also an attractive ornamental plant. The second example involved crossing a V. darrowi selection, 'NC 84-6-5,' with a selection of V. cylindraceum, 
'NC 3730' (section Hemimyrtillus). Vaccinium cylindraceum has an upright growth habit and extremely long fruit pedicels within a very loose inflorescence, each of which are potentially useful traits for adaptation to mechanical harvesting. This hybrid combination resulted in a small progeny arising from a modest number of pollinations, and one seedling, 'NC 3865', was tetraploid. The remaining diploid $\mathrm{F}_{1} \mathrm{~s}$ gradually declined in vigor over time and died. 'NC 3865 ' has been successfully backcrossed to both standard and southern highbush, and the backcross progenies have been established in the field. In addition, the two intersectional amphidiploid genotypes ( $\mathrm{NC}$ 3048' and 'NC 3865') have been successfully intercrossed and produced a small progeny of relatively vigorous trisectional hybrids. Several of these hybrids were successfully intercrossed recently, and so they also appear to be at least partly fertile.

These examples demonstrate that gene transfer by conventional means among sections in Vaccinium can be a viable option, where needed to achieve specific goals. They also provide additional support for the hypothesis of a highly conserved basic genome in the genus (Hall and Galletta, 1971).

\section{PRESERVATION}

Maintenance and preservation of Vaccinium genetic resources within the U.S. National Plant Germplasm System is assigned to the USDA, ARS, National Clonal Germplasm Repository in Corvallis, Ore. (Hummer, 1998). The Corvallis collection includes taxa of $\approx 60$ Vaccinium species and 258 named cultivars or elite selections obtained from 26 countries. These numbers are constantly changing as the Repository is acquiring additional germplasm on a more or less continuing basis. The most publicly accessible information concerning the current status of the collections is available on the web by searching the Genetic Resources Information Network (GRIN) system (www.ars-grin.gov/npgs). Species are primarily represented by seed lots held in long-term storage along with a small number of clonal representatives. The primary clonal collection is maintained in a screenhouse, with additional plants in the field. A core collection has been designated by the curator, in consultation with the Small Fruit Crop Germplasm Committee, to represent $\approx 95 \%$ of the diversity within the collections. About $20 \%$ of the clonal collection is backed up with plants held in vitro at $4{ }^{\circ} \mathrm{C}$. Accessions maintained at the Repository have been obtained from collaborators around the world and from certain of the plant germplasm collecting expeditions cited in the section above on collecting. A significant amount of germplasm is also maintained, at least in the short term, in the working collections of Vaccinium breeding and genetics programs.

Table 1 summarizes the germplasm currently maintained at Corvallis for species in nine important or potentially important sections in Vaccinium that are available for distribution. It is not indicative of the total germplasm of these species that is maintained by the Repository, but only that which is available for distribution. Given that there should be no major quarantine backlog with any of these species due to systemic pathogen infection, the numbers in this table, as well as the total number maintained, are quite modest for many species. Therefore, several points are obvious when examining Table 1. First, for the present, the primary genepools for cranberry and lingonberry appear to be adequately represented. Second, the primary genepools for the major cultivated types in section Cyanococcus ( $V$. angustifolium, $V$. amoenum-V. ashei, V. corymbosum), as well as in $V$. darrowi, which has been so important in southern highbush breeding, are poorly represented. On first glance this may not appear to be true with $V$. corymbosum; however, 128 of the clonal accessions listed are cultivated clones, (i.e., a relatively narrow genepool). Third, a number of species, including $V$. darrowi and $V$. elliottii, are represented by less than five seed lots. Vaccinium uliginosum, V. membranaceum Dougl., and $V$. ovalifolium Smith, none of which are currently cultivated, are all represented by modest collections, but all three are also better represented with regard to seed accessions than are $V$. corymbosum, $V$. augustifolium, V. amoenum, V. ashei, or V. darrowi.

When comparing the scope of recent collections outlined herein with the limited germplasm available from the Repository listed in Table 1, a logical question is, why does this situation exist? Simply put, most of the Vaccinium germplasm collected since the mid-1960s was collected for evaluation and utilization by the breeder(s) and or geneticist(s) involved in the collecting. A high percentage of such germplasm, particularly in species utilized in cultivar development, was probably discarded following local utilization by the breeder, or lost due to inability of individual programs to maintain large quantities of such germplasm for long periods of time. In addition, a significant percentage of recent Vaccinium germplasm collections were made prior to the establishment of the Clonal Repository at Corvallis, when no such facility existed for this genus.

The solution to this situation is well within reach. Extensive in situ populations of all these species still exist, and, where deemed appropriate, they are still available for collecting. However, highest priorities need to be directed toward encouraging recent collectors to share clones and, especially, viable remnant seeds from their collections with the Repository. Once this has been successfully executed, the situation can be reassessed, and additional collections made if needed.

Table 1. Available Vaccinium accessions in nine sections of the genus maintained at the U.S. Dept. of Agriculture, National Clonal Germplasm Repository at Corvallis, Ore., in 1999. ${ }^{\mathrm{z}}$

\begin{tabular}{|c|c|c|c|}
\hline Section and species ${ }^{y}$ & $\begin{array}{l}\text { Seed } \\
\text { (no.) }\end{array}$ & $\begin{array}{c}\text { Clonal } \\
\text { (no.) }\end{array}$ & $\begin{array}{l}\text { Total } \\
\text { (no.) }\end{array}$ \\
\hline \multicolumn{4}{|l|}{ Cуапососсиs } \\
\hline V. атоепит & 2 & 15 & 17 \\
\hline V. angustifolium & 6 & 11 & 17 \\
\hline V. ashei & 5 & 35 & 40 \\
\hline V. boreale & 1 & 2 & 3 \\
\hline V. constablaei & 1 & 6 & 7 \\
\hline V. corymbosum & 29 & 155 & 184 \\
\hline V. darrowi & 3 & 2 & 5 \\
\hline V. elliottii & 1 & 18 & 19 \\
\hline V. hirsutum & 0 & 0 & 0 \\
\hline V. myrtilloides & 4 & 1 & 5 \\
\hline V. myrsinites & 0 & 0 & 0 \\
\hline V. pallidum & 13 & 2 & 15 \\
\hline V. simulatum & 22 & 5 & 27 \\
\hline V. tenellum & 2 & 4 & 6 \\
\hline \multicolumn{4}{|l|}{ Oxycoccus } \\
\hline V. macrocarpon & 36 & 91 & 127 \\
\hline V. oxycoccos & 18 & 12 & 30 \\
\hline \multicolumn{4}{|l|}{ Vitis-idaea } \\
\hline V. vitis-idaea & 39 & 51 & 90 \\
\hline \multicolumn{4}{|l|}{ Vaccinium } \\
\hline V. uliginosum & 48 & 0 & 48 \\
\hline \multicolumn{4}{|l|}{ Pyxothamnus } \\
\hline V. consangineum & 0 & 1 & 1 \\
\hline V. corymbodendron & 0 & 2 & 2 \\
\hline V. floribundum & 12 & 1 & 13 \\
\hline V. ovatum & 18 & 14 & 32 \\
\hline \multicolumn{4}{|l|}{ Batodendron } \\
\hline V. arboreum & 20 & 9 & 29 \\
\hline \multicolumn{4}{|l|}{ Polycodium } \\
\hline V. stamineum & 10 & 1 & 11 \\
\hline \multicolumn{4}{|l|}{ Myrtillus } \\
\hline V. cespitosum & 5 & 0 & 5 \\
\hline V. deliciosum & 10 & 0 & 10 \\
\hline V. membranaceum & 55 & 5 & 60 \\
\hline V. myrtillus & 28 & 1 & 29 \\
\hline V. ovalifolium & 54 & 20 & 74 \\
\hline$V \cdot$ parvifolium & 30 & 4 & 34 \\
\hline \multicolumn{4}{|l|}{ Hemimyrtillus } \\
\hline V. arctostaphylos & 1 & 1 & 2 \\
\hline V. cylindraceum & 1 & 2 & 3 \\
\hline V. padifolium & 1 & 2 & 3 \\
\hline
\end{tabular}

${ }^{2}$ Adapted from Table 2 in Hummer (1998), and updated by Hummer (pers. comm., 2000).

${ }^{\mathrm{y} S p e c i e s ~ d e l i m i t a t i o n s ~ a s ~ l i s t e d ~ i n ~ L u b y ~ e t ~ a l . ~(1991), ~ a n d ~ G a l l e t t a ~ a n d ~ B a l l i n g t o n ~}$ (1996). 
Furthermore, equal sharing of collected germplasm between collector(s) and the Repository should be a requirement for all future collecting expeditions sponsored by the USDA Plant Exploration Laboratory.

\section{SUMMARY AND CONCLUSIONS}

Blueberries, cranberries, and lingonberries, the three commercial crops developed from species or species hybrids in the genus Vaccinium, are all of fairly recent to recent origin (185 years or less), are expanding rapidly in both volume and area of production, and promise to become more important world crops. The germplasm base in lowbush blueberries and lingonberries is quite diverse, because most fruit is still harvested from native stands, while in cultivated highbush and rabbiteye blueberries it is quite narrow. Genetic diversity in commercial cranberries is also narrow, since only five cultivars account for $90 \%$ of the hectarage. Native germplasm resources potentially available within the primary genepools of lingonberries and of lowbush, highbush, and rabbiteye blueberries are almost unlimited. Germplasm resources in cranberry may be somewhat more restricted because of destruction of wetland habitats, but also are still fairly extensive. Germplasm resources in the secondary and tertiary genepools for all these crops are also generally extensive.

Germplasm collecting expeditions over the last 35 years have resulted in significant collections of species of blueberries in seven sections of the genus, and minor collections in many others. Significant collection of both cranberry species and lingonberry has also taken place.

Significant advances have been made in broadening the germplasm base in highbush blueberries, and five recently introduced highbush cultivars involve native highbush germplasm in their genetic backgrounds. Wild $x$ cultivated highbush crosses continue to be important in developing cultivars adapted to mechanical harvesting. In the secondary genepool of highbush, $V$. darrowi and its hybrids with $V$. ashe $i$ have served as valuable sources of genes for southern adaptation, and 20 cultivars of "southern highbush" with this species or species hybrid in their background have been released. Vaccinium angustifolium continues to be a significant source of genes for improving highbush cultivars, including genes for stem blight resistance. Vaccinium elliottii contributes genes for adaptation to upland cultivation and to warmer climates, along with resistance to stem blight, to the highbush genepool.

Minor but significant efforts to broaden the germplasm base in the primary genepool of the rabbiteye blueberry have been made, but none has yet resulted in release of cultivars. In the secondary genepool, $\mathrm{F}_{1}$ hybrids and backcrosses involving $V$. constablaei have resulted in release of two cultivars, and this approach still appears promising. The development of hexaploid southern highbush genotypes appears very promising for combining the fruit quality and early-ripening characteristics of highbush with the adaptability and productivity of rabbiteye in new hexaploid hybrid genotypes.

Cultivar improvement work with the lowbush blueberry, American cranberry, and lingonberry has almost exclusively utilized the very extensive and diverse germplasm resources within the primary genepool of each species. The same is true for the fairly recently released cultivars of tetraploid European cranberry in Estonia. In cranberry, limited successful interspecific hybridization studies have only recently begun involving crossing diploid forms of $V$. oxycoccos with $V$. macrocarpon.

Intersectional hybridization (the tertiary genepool) in Vaccinium has a long history going back to Coville in the early years of the 20th century. At least 20 different intersectional hybrid combinations have resulted in production of viable hybrid seedlings. Reproductive isolation barriers only appear to a significant degree in hybrids at the sectional level in this genus, and these hybrids typically exhibit varying degrees of cytogenetic and morphological irregularities. Diploid intersectional hybrids are typically sterile or nearly so, but exceptions occur. Cytogenetic and morphological irregularities are also evident to varying degrees with tetraploid intersectional hybrids; however, fertility and normal morphological development can often be restored with backcrossing. This has been demonstrated in Cyanococcus-Vaccinium and Cyanococcus-Pyxothamnus combinations in particular. One at least partially fertile tetraploid progeny involving germplasm from three sections has recently been generated. Therefore, conventional gene transfer from the tertiary genepools of the cultivated types is realistic in a number of cases.

Clonal collections of cranberry and lingonberry maintained at NCGR-Corvallis are adequate for the immediate future. However, seed and clonal collections of highbush, rabbiteye, and lowbush blueberries, as well as most species in their secondary genepools, are inadequate. Seed collections of many other species may also be inadequate. Increased sharing of seed and elite, wild, clonal germplasm from the working collections of Vaccinium breeders and geneticists with the Repository would probably go a long way toward alleviating this situation, especially with the cultivated species and their close relatives. If not, the abundant native germplasm resources in most of these species are still available for collection.

\section{Literature Cited}

Aalders, L.E., I.V. Hall, and L.P. Jackson. 1977. ‘Brunswick' lowbush blueberry. Can. J. Plant Sci. 57:301.

Aalders, L.E., A.A. Ismail, I.V. Hall, and P.R. Helpler. 1975. 'Augusta' lowbush blueberry. Can. J. Plant Sci. 55:1079.

Ahokas, H. 1971. Notes on polyploidy and hybridity in Vaccinium species. Ann. Bot. Fenn. 8:254-256.

Ahokas, H. 1979. Artificial reciprocal hybrids between Vaccinium microcarpum and Vaccinium vitis-idaea. Ann. Bot. Fenn. 16:3-6.

Ballington, J.R. 1990. Germplasm resources available to meet future needs for blueberry cultivar improvement. Fruit Var. J. 44:54-62.

Ballington, J.R., Y.M. Isenberg, and A.D. Draper. 1986. Flowering and fruiting characteristics of Vaccinium ashei and Vaccinium ashei-Vaccinium constablaei derivative blueberry progenies. J. Amer. Soc. Hort. Sci. 111:950955.

Ballington, J.R., W.B. Kirkman, D.V. Barkley, and A.F. Huyler. 1979. Vaccinium germplasm collections; North Carolina and South Carolina, 1978 and 1979. Hort. Crops Res. Ser. No. 51, North Carolina State Univ., Raleigh.

Ballington, J.R., W.B. Kirkman, W.H. Gensel, Y.M. Isenberg, and C.A, Walker. 1982. Vaccinium germplasm collections, 1980-1982. Hort. Crops Res. Ser. No. 60, North Carolina State Univ., Raleigh.

Ballington, J.R., W.B. Kirkman, C.A. Walker, B.L. Shoemaker, and D. Finch. 1985. Small fruit crops germplasm collections, 1983-1985. Hort. Crops Res. Ser. 71, North Carolina State Univ., Raleigh.

Ballington, J.R., J.J. Luby, and O.L. Jahn. 1988. Small fruit germplasm collection in the Pacific Northwest. Diversity 16:24-25.

Ballington, J.R., J.L. Luteyn, M.M. Thompson, K. Romoleroux, and R. Castillo. 1993a. Rubus and Vacciniaceous germplasm resources in the Andes of Ecuador. FAO/ IBPGP Plant Genet. Resources Nwsl. 93:9-15.

Ballington, J.R., S.D. Rooks, W.O. Cline, J.R. Meyer, and R.D. Milholland. 1997. The North Carolina blueberry breeding program: Towards $V$. covillanum? Acta. Hort. 446:243-247.

Ballington, J.R., S.D. Rooks, R.D. Milholland, W.O. Cline, and J.R. Meyer. 1993b. Breeding blueberries for pest resistance in North Carolina. Acta. Hort. 346:87-94.

Batchelor, J.M. 1965. The rabbiteye blueberry-An old and new horticultural fruit for the southern United States, p. 97-101. In: 56th Annu. Rpt. Northern Nut Growers Assoc., Univ. of Missouri, Columbia.

Bruederle, L.P. and N. Vorsa. 1994. Genetic differentiation of diploid blueberry Vaccinium section Cyanococcus (Ericaceae). Syst. Bot. 19:337-349.

Buckley, B. and J.R. Ballington. 1987. Screening native Vaccinium species for resistance to stem blight. HortScience 22:101.

Camire, M.A. 1997. U.S. changes in health claims and nutritional labelling for foods and dietary supplements. Acta. Hort. 446:205-209.

Camp, W.H. 1945. The North American Blueberries with notes on other groups of Vacciniaceae. Brittonia 5:203-275.

Caruso, F.L. 1997. Trends in cranberry production. Acta. Hort. 446:41-45

Chandler, F.B., and I. Demoranville. 1958. Cranberry varieties of North America. Massachusetts Agr. Expt. Sta. Bul. 513

Coville, F.V. 1910. Experiments in blueberry culture. USDA Bur. Plant Ind. Bul. 193.

Coville, F.V. 1937. Improving the wild blueberry, p. 559-574. In: Yearbook of Agriculture, U.S. Dept. Agr., 1937.

Darrow, G.M. and W.H. Camp. 1945. Vaccinium hybrids and the development of new horticultural material. Bul. Torrey Bot. Club 72:1-21.

Dierking, W., S. Dierking, and W. Dierking Beerenobst. 1993. European Vaccinium species. Acta. Hort. 346:299-304.

Doughty, C.C. 1960. Research project progress report. Washington State Agr. Expt. Sta., Pullman.

Doughty, C.C. 1962. Research project progress report. Washington State Agr. Expt. Sta., Pullman 
Dweikat, I.M. and P.M. Lyrene. 1989. Production and evaluation of a synthetic hexaploid in blueberry. Theor. Appl. Genet. 77:799-804.

Ehlenfeldt, M.K. 1997. Breeding blueberries for the new century. Acta. Hort. 446:227-233.

Ehlenfeldt, M.K. and N. Vorsa. 1993. The generation, evaluation and utilization of hexaploid progeny from $3 \times$ x $3 x$ crosses of highbush blueberry. Acta. Hort. 346:95-102.

Estabrooks, E.N. 1997. Native lingonberry (Vaccinium vitis-idaea var. minus) as a new crop in New Brunswick, Canada. Acta. Hort. 446:125-127.

Food and Agriculture Organization. 1999. FAOSTAT database collections. Rome, Italy. http://apps.fao. org/egi-bin/nph-db.pl?subset=agriculture.

Galletta, G.J. and J.R. Ballington. 1996. Blueberries, cranberries and lingonberries, p. 1-107. In: J. Janick and J.N. Moore (eds.). Fruit breeding. Vol. II, Vine and small fruit crops. Prentice Hall, New York.

Gorbunov, A.B. 1993. Introduction and breeding of Vacciniaceae in Siberia Acta. Hort. 346:103-106.

Gronskis, I. and A. Snickovskis. 1989. Organization of cranberry growing in Latvia. Acta. Hort. 241:77-80.

Gustavsson, B.A. 1997. Breeding strategies in lingonberry culture (Vaccinium vitis-idaea) Act. Hort. 446:129-137.

Hall, I.V. and L.E. Aalders. 1982. 'Blomidon' lowbush blueberry. Can. J. Plant Sci. 62:519-521.

Hall, I.V., L.E. Aalders, and L.P. Jackson. 1977. 'Chignecto' lowbush blueberry. Can. J. Plant Sci. 57:1217-1218

Hall, I.V., L.E. Aalders, N.L. Nickerson, and S.P. Vander Kloet. 1979. The biological flora of Canada. 1. Vaccinium angustifolium Ait., sweet lowbush blueberry. Can. Field Naturalist 93:415-430.

Hall, I.V., A.R. Jamison, and A.D. Brydon. 1988. 'Cumberland' and 'Fundy' lowbush blueberries. Can. J. Plant Sci. 68:553-555.

Hall, S.H. and G.J. Galletta. 1971. Comparative chromosome morphology of diploid Vaccinium species. J. Amer. Soc. Hort. Sci. 96:289-292.

Hancock, J.F. 1998. Using southern blueberry species in northern highbush breeding, p. 92-94. In: W.O. Cline and J.R. Ballington (eds.). Proc. 8th. North Amer. Blueberry Res. and Ext. Workers Conf., 27-29 May 1998. Wilmington, N.C.

Hancock, J.F., W.A. Erb, B.L. Goulart, and J.C. Scheerens. 1995. Utilization of wild blueberry germplasm: The legacy of Arlen Draper. J. Small Fruit Viticult. 3:1-16

Hancock, J.F. and S.L. Krebs. 1986. Cytoplasms of highbush blueberry cultivars. Fruit Var. J. 40:49-50.

Hiirsalmi, H.M. 1988. Small fruit breeding in Finland. J. Agr. Sci. Finland 60:223-234.

Hiirsalmi, H.M. and A. Lehmushovi. 1982. A Finnish highbush blueberry variety 'Aron.' Agr. Fenn. 21:151-154.

Hummer, K.E. 1998. Management of Vaccinium genetic resources at the NCGR. p. 95-100. In: W.O. Cline and J.R. Ballington (eds). Proc. 8th North Amer. Blueberry Res. and Ext. Workers Conf., 27-29 May 1998. Wilmington, N.C.

Hummer, K.E. and C.I. Wright. 1996. Trip to south-central Alaska to collect small fruit genera for the USDA ARS National Clonal Germplasm Repository. Natl. Clonal Germplasm Repository Sta. Rpt.

Hunn, E.S. and H.H. Norton. 1983. Impact of Mt. St. Helens ashfall on fruit yield of mountain huckleberry, Vaccinium membranaceum, important native American food. Econ. Bot. 38:121-127.

Joseph, J.A., B. Shukitt-Hale, N.A. Denisova, D. Bielinski, A. Martin, J.J. McEwen, and P.C. Bickford. 1999. Reversals of age-related declines in neuronal signal transduction; cognitive, and motor behavioral deficits with blueberry, spinach or strawberry dietary supplementation. J. Neurosci. 19:8114-8121.

Kirkman, W.B. 1987. The taxonomy, ecology and horticulture of Vaccinium section Herpothamnus (Ericaceae). PhD Diss., Dept. of Horticulture, North Carolina State Univ., Raleigh.

Kirkman, W.B. and J.R. Ballington. 1985. 'Wells Delight' and 'Bloodstone' creeping blueberries. HortScience 20:1138-1140.

Laverty, T. and N. Vorsa. 1991. Fertility of aneuploids between the 5x and 6x levels in blueberry: The potential for gene transfer from $4 \mathrm{x}$ to $6 \mathrm{x}$ levels. J. Amer. Soc. Hort. Sci. 116:330-335.
Lehmushovi, A. 1977. Trials with the cowberry in Finland. Acta. Hort. 61:301308.

Lehmushovi, A., H. Hokkanen, and H. Hiirsalmi. 1993. Cranberry breeding in Finland. Acta. Hort. 346:322-326.

Luby, J.J., J.R. Ballington, A.D. Draper, K. Pliszka, and M.E. Austin. 1991 Blueberries and cranberries (Vaccinium). Acta Hort. 290:391-456.

Lyrene, P.M. 1988. Breeding rabbiteye blueberries. Plant Breeding Rev. 5:307-357.

Lyrene, P.M. 1990. Sparkleberry x blueberry crosses. HortScience 25:1168.

Lyrene, P.M. 1991. Fertile derivatives from sparkleberry $x$ blueberry crosses J. Amer. Soc. Hort. Sci. 116:899-902.

Lyrene, P.M. 1993. Some problems and opportunities in blueberry breeding. Acta. Hort. 346:63-71.

Lyrene, P.M. 1998. Ralph Sharpe and the Florida blueberry breeding program, p. 1-7. In: W.O. Cline and J.R. Ballington (eds.). Proc. 8th North Amer. Blueberry Res. and Ext. Workers Conf., 27-29 May 1998. Wilmington, N.C.

Lyrene, P.M. and J.R. Ballington. 1986. Wide hybridization in Vaccinium. HortScience 21: 52-57.

Lyrene, P.M. and S.J. Brooks. 1995. Use of sparkleberry in breeding highbush blueberry cultivars. J. Small Fruit Viticult. 3:29-38.

Lyrene, P.M. and J.A. Payne. 1995. Blueberry gall midge : A new pest of rabbiteye blueberries, p. 111-124. In: R.E. Gough and R.F. Korcak (eds.) Blueberries : A century of progress. Haworth Press, Binghamton, N.Y.

Lyrene, P.M. and W.B. Sherman. 1980. Horticultural characteristics of native Vaccinium darrowi, V. elliottii, V. fuscatum and V. myrsinites in Alachua County, Fla. J. Amer. Soc. Hort. Sci. 105:393-396.

Meyer, J.R. and J.R. Ballington. 1990. Resistance of Vaccinium spp. to the leafhopper Scaphytopius magdalensis (Homoptera:Cicadellidae). Ann. Entomol. Soc. Amer. 83:515-520.

Moore, J.N. 1966. Breeding, p. 45-74. In: P. Eck and N.F. Childers (eds.). Blueberry culture. Rutgers Univ. Press. New Brunswick, N.J.

Munoz, C.E. 1993. Overview of the blueberry industry in South America. Acta Hort. 346:27-32.

Pliszka, K. 1993. The blueberry industry and research in eastern Europe. Acta Hort. 346:41-43.

Prior, R.L., G. Cao, A. Martin, E. Sofic, J. McEwen, C. O’Brien, N. Lischner, M. Ehlenfeldt, W. Kalt, G. Krewer, and C.M. Mainland. 1998. Antioxidant capacity as influenced by total phenolic and anthocyanin content, maturity, and variety of Vaccinium species. J. Agr. Food Chem. 46:26862693.

Pritts, M.P. and J.F. Hancock. 1984. Independence of life history parameters in populations of Vaccinium angustifolium (Ericaceae). Bul. Torr. Bot. Club $111: 451-461$

Pritts, M.P. and J.F. Hancock. 1985. Lifetime biomass partitioning and yield component relationships in highbush blueberry (Vaccinium corymbosum L. (Ericaceae) Amer. J. Bot. 72:446-452.

Pritts, M.P., J.F. Hancock, and J.M. Roche. 1985. Identifying superior genotypes of blueberry in wild populations. HortScience 20:409-411.

Sharpe, R.H. 1954. Horticultural development of Florida blueberries. Proc. Florida State Hort. Soc. 66:188-190.

Shultz, J.H. 1944. Some cytotaxonomic and germination studies in the genus Vaccinium. PhD Diss., Washington State Univ., Pullman.

Stevens, P.F. 1969. Taxonomic studies in the Ericaceae. PhD Diss., Univ. of Edinburgh, Edinburgh, U.K.

Teär, J. 1972. Vegetativ och fruktifikativ utveckling hos vild vaxande och adlade longon. Adv. for frukt och barodling, Alnarp, Sweden.

Trinka, D.L. 1997. Production trends in the cultivated blueberry industry of North America. Acta. Hort. 446:37-39.

Vander Kloet, S.P. 1988. The genus Vaccinium in North America. Agr. Can Publ. 1828.

Yarborough, D.E. 1997. Production trends in the wild blueberry industry in North America. Acta. Hort. 446:33-35.

Zeldin, E.L. and B.H. McCown. 1997. Intersectional hybrids of lingonberry (Vaccinium vitis-idaea, section Vitis-idaea) and cranberry (V. macrocarpon, section Oxycoccus) to Vaccinium reticulatum (section Macropelma). Acta. Hort. 446:235-238. 